\title{
Counter-stories: Maintaining AND Expanding Civil Liberties in Wartime
}

\section{Mark A. Graber}

Constiturional lawyers and historians frequently tell stories about how civil liberties and civil rights in the United States are restricted during wartime. The first major federal restrictions on civil liberties, the Alien and Sedition Acts of 1798 , were enacted while the federal government was dealing with its first major military conflict, the undeclared naval war with France. ${ }^{1}$ President Abraham Lincoln during the Civil War unilaterally imposed martial law in the North and censored the Copperhead press. ${ }^{2}$ Left-wing dissidents and aliens who opposed military intervention were persecuted during the First World War. ${ }^{3}$ During the Second World War, martial law was imposed in Hawaii and Japanese-Americans were forcibly removed to internment camps. ${ }^{*}$ The cold war inspired McCarthyism. ${ }^{5}$ Massive detentions without trial or aid of counsel are taking place during the present war against terrorism. ${ }^{6}$

These common accounts of restrictive policies during wartime do not tell the complete tale of how military conflicts and tensions influence civil rights and liberties in the United States. Some civil rights and liberties have historically been unaffected by war. Military action in American history is not associated with any substantial rise in the annual rate of executions or new restrictions on reproductive rights. Many restrictions on civil liberties are selectively applied. Right-wing critics of American policymaking during the First World War were not persecuted. German-Americans during the Second World War were not sent to internment camps. Restrictive policies adopted during one war are not adopted in subsequent wars. ${ }^{7}$ Contempo- 
rary left-wing opponents of the war against terror are far freer to criticize government policy than were left-wing opponents of the First World War. American Muslims have no curfew and are not being rounded up en masse. Some military conflicts are never mentioned when the canonical stories abour civil rights in wartime are told. The War of I8I2, the MexicanAmerican War, and the Spanish-American War were fought without any substantial federal restrictions on civil rights and civil liberties. ${ }^{8}$

The canonical narratives also omit numerous instances in which military conflict inspired some government officials to increase protections for civil rights and liberties. The national commitment to racial equality increased substantially during the Civil War, the Second World War, and the cold war. ${ }^{9}$ The Supreme Court in West Virginia State Board of Education v. Barnette (1943) ${ }^{10}$ held that the government could not compel students to salute the flag, overruling its pre-war decision in Minerswille School Dist. v. Gobitis (1940). ${ }^{11}$ Government repression aimed at socialists and communists eased substantially during the Second World War. Persons who criticize the Bush administration for violating the constitutional rights of aliens do not praise that administration's unyielding commitment during the war against terrorism to the rights of gun owners. Some of these stories are told, but as part of other narratives such as the history of racial equality or free speech in the United States. Some are hardly ever recounted. None is presently part of a grand narrative about civil liberties and rights policy in the United States during wartime.

This chapter is a preliminary attempt to integrate these counter-stories of when rights were protected and expanded during wartime into the general narrative of civil liberties policy during war and periods of military tension. ${ }^{12}$ The first part recounts numerous instances when civil rights and civil liberties were either protected or expanded during hot or cold wars. These accounts, while not intended to be comprehensive, provide evidence that policies protective of rights in the United States during wartime have been approximately as frequent, have affected approximately as many people, and have been as concerned with fundamental liberties as restrictive policies. The second part of the chapter sketches some counter-stories of civil rights protected or expanded during the present war against terrorism. The same factors that have historically explained why some rights are restricted, others protected, and still others expanded during particular wars, the analysis suggests, continue to structure contemporary responses to military conflict. 
The chapter concludes by noting how incorporating the counter-stories into grand narratives about civil rights and liberties in wartime provides a better perspective on the policies of the Bush administration.

Protection and expansion of civil rights and civil liberties during hot and cold wars do not occur at random, but take place regularly whenever some combination of the following four conditions is present: ${ }^{13}$

I. "[A] large-scale war requir [es] extensive economic [or] military mobilization of [the beneficiaries of a rights protective policy] for success."14

2. " $[\mathrm{T}]$ he nature of America's enemies ... prompt [s] American leaders to justify such wars and their attendant sacrifices by emphasizing the nation's inclusive, egalitarian, democratic traditions"15 or, at least, the national commitment to particular civil rights and liberties.

3. The beneficiaries of the civil right or liberty are, for reasons of race, ethnicity, or ideology, identified as loyal Americans, as aligned with American allies or countries whose support the United States is seeking, or at least as enemies of America's enemies.

4. Powerful political actors inside and outside government see the military conflict as an additional reason for advancing existing commitments to particular civil liberties and rights. Other crucial government actors can be persuaded or pressured to support those rights or liberties. ${ }^{16}$

Civil rights and liberties are likely to be restricted, by comparison, whenever the beneficiaries of protective policies are ideologically or ethnically identified with America's enemies or when government officials see the military conflict as an additional reason for advancing existing commitments to further limit the right or liberty in question.

This fuller but by no means complete story of civil liberties policy during wartime supports two additional conclusions. ${ }^{17}$ First, civil liberties policy has historically varied by war and issue. Rights policies vary within wars and between wars. The Civil War witnessed substantial restrictions on free speech rights and substantial increases in the rights enjoyed by persons of color. The Second World War was easy on political dissidents and hard on Japanese-Americans. Speech rights were substantially restricted during the American Revolution, the undeclared war with France, the Civil War, the First World War, and the cold war, but not during the War of 1812 , the Mexican War, the Spanish-American War, the Second World War, or during the present war against terrorism. Second, decisions to restrict civil rights and liberties during a war result from subjective choices rather than from 
objective necessities. Political dissent has been as widespread and as intense during wars in which speech was not restricted as during wars in which speech was restricted. Japanese-Americans during the I940s were no more disloyal or loval than German-Americans (and they were probably far more loyal than German-Americans during the First World War). Whether government officials restrict liberty, history suggests, depends more on ethnic stereotypes and contestable beliefs about the value of civil liberties than on clear threats presented by the exercise of a particular right during a particular war.

\section{SOME COUNTER-STORIES}

Four kinds of stories can be told about civil liberties and civil rights in wartime. The conventional stories are about restrictive policies adopted in the name of national security. Non-stories are about the absence of any or particular civil liberties issues during war or particular wars. These narratives, analogous to the tale of the dog that did not bark in the night, counter careless claims that military conflicts or tensions consistentiy produce generalized pressures to limit all existing individual rights. Some counterstories are about how wartime proposals for new restrictive policies were defeated. These narratives demonstrate that Americans, at least under certain conditions, are capable of resisting efforts to limit civil liberties and rights during wartime. Other counter-stories are about how particular civil rights and civil liberties were expanded during wartime. These narratives demonstrate that Americans, in almost every major instance of military conflict or tension, have thought that mobilization needs, rewards for loyalty, or concerns not to emulate policies identified with national enemies have justified providing more protection for some individual rights.

The stories told below are about political actors making explicit connections between domestic civil liberties and an existing military situation. The canonical stories about occasions when civil liberties were restricted in wartime tell of policymakers claiming that the exercise of a particular right threatens national security. The counter-stories about occasions when civil liberties were expanded in wartime tell of policymakers claiming that protective policies promote national security or are intertwined with the justification for military force. Other stories about the relationship between war 
and civil liberties can be told, focusing on the unintended consequences of war.

Abortion policies after the Second World War are a good example of the difference between conscious and unintended consequences of war on civil rights policy. European policymakers frequently justified cold war abortion policies by pointing to the consequences of past military conflicts on future military needs. "[T] he devastating effects of World War II on the population," Berta Hernandez-Truyol notes, "prompted many Eastern European states to outlaw abortion in the hopes of increasing population to reestablish the labor force and rebuild armies." 18 The leading postwar opponents and proponents of abortion rights in the United States, by comparison, did not point to the cold war when justifying their preferred policy. National security concerns played, at most, a very minor role in arguments about family policy. Proponents of abortion rights rarely emphasized the need to distinguish American abortion policies from those implemented by national enemies. The Second World War significantly influenced family policy in the United States, primarily through the further loosening of sexual mores and the resulting postwar demands for a return to normalcy. ${ }^{19}$ The terrain in which arguments about abortion were made was altered by war, but war did not directly affect those arguments.

The remainder of this chapter focuses on the connections that political actors self-consciously drew between civil rights policy and the military conflicts in which they were engaged.

\section{Non-stories}

War throughout American history has not exerted any general, across-theboard pressure to restrict all civil rights and civil liberties. Government officials during particular wars at most propose to limit particular civil rights and liberties. They do not propose to restrict civil rights and liberties whenever the United States is faced with a military threat, and they have never responded to a military threat by proposing to restrict all civil rights and liberties. No major rights controversies are associated with the War of 1812 or the Mexican War. No significant changes in the rate of executions or in birth control policies are directly associated with any military conflict. Some civil liberties controversies have erupted only during certain wars. The Sec- 
ond World War is the only military conflict associared with significant increases or decreases in religious freedom. More than two hundred years passed before even a minor Second Amendment controversy flared during a war. The Third Amendment has never been tested while the United States is at war.

\section{Racial (and Gender) Equality}

The struggle for racial equality provides numerous counter-stories of how civil rights were expanded during wartime and periods of military tension. During the cold war, support for desegregation was partly rooted in perceived needs to increase American popularity abroad. Brown v. Board of Education, Derrick Bell declares, "helped to provide immediate credibility to America's struggle with Communist countries to win the hearts and minds of emerging third world peoples."20 Mary Dudziak elaborates Bell's insight at great length and with much sophistication when detailing the ways in which the cold war inspired, structured, and limited racial liberalism during the mid-twentieth century. Her study emphasizes that government officials regarded measures aimed at expanding African American freedom as crucial to American struggles against the Soviet Union. "[E]fforts to promote civil rights within the United States," Dudziak details, "were consistent with and important to the more central U.S. mission of fighting world communism."21 Legal briefs frequently reminded courts that decisions furthering civil rights would have favorable national security consequences. The Justice Department in Brown informed the justices that "racial discrimination in the United States remains a source of constant embarrassment to this Government in the day-to-day conduct of its foreign relations." Jim Crow, the brief for the federal government continued, "jeopardizes the effective maintenance of [American] moral leadership of the free and democratic nations of the world."22

Philip Klinkner and Rogers Smith extend the connection between military threats and the civil rights of African Americans far beyond the cold war. Military conflict, they observe, has historically been the primary vehicle for securing greater racial equality in the United States. Every major improvement in the condition of African Americans, Klinkner and Smith point out, has been closely associated with a war. The rhetoric of liberty that 
inspired the colonists to declare independence and take up arms against Great Britain was simultaneously employed to justify emancipation in the North, bans on the importation of slaves, and laws easing manumission in the slave states. ${ }^{23}$ The Civil War destroyed slavery and, as the heroism of black troops became known, inspired many northern states to repeal racist policies. Racial barriers began falling in northern states as the wartime service of African Americans fostered more egalitarian attitudes. One Union officer wrote, "You have no idea how my prejudices with regard to the negro troops have been dispelled by the battle the other day."24 The first federal decrees desegregating the workplace were issued during the Second World War, when the United States had substantial need of African American troops and laborers. Military service again proved a vehicle for dispelling racial prejudice, clearing a path for the civil rights movement of the next decade. ${ }^{25}$ Americans dissarisfied with the present racial status quo, this analysis might suggest, should consider imitating the fictional duchy of Grand Fenwick and find a powerful opponent to declare war against. ${ }^{26}$

Klinkner and Smith highlight two direct connections between certain wars and increased racial equality. Policymakers promote racial equality, they claim, when the war effort requires African Americans to fight for victory, and when egalitarian commitments are intertwined with the justification for the war. ${ }^{27}$ African American troops played significant roles in the Civil War, the Second World War, and to a lesser extent the American Revolution. The Confederacy, Nazi Germany, and the Soviet Union inspired renewed commitment to the principles of human liberty and equality that inspired the American Revolution. Just as significantly, African Americans had no ethnic, racial, or ideological ties to the American South or Nazi Germany that might have created the suspicions of a "fifth column" that haunted Japanese-Americans during the Second World War. Some black communists did have ideological ties to the Soviet Union, but most policymakers during the 1950 and 1960 s placed greater emphasis on the racial ties between African Americans and those third world countries deemed crucial supporters of American efforts during the cold war.

Proponents of racial equality were well positioned to take advantage of their windows of opportunity during the Civil War, the Second World War, and the cold war. Klinkner and Smith emphasize that strong protest movements were already in place that could pressure government officials to improve the status of African Americans. ${ }^{28}$ Of equal importance, govern- 
ment officials during the Civil War, the Second World War, and the cold war were either sympathetic to racial liberalism or not implacably wedded to the racial status quo. President Andrew Johnson's actions during Reconstruction suggest that the favorable conditions for improving the status of African Americans during the Civil War would have had a much lesser impact on public policy had a northern Democrat been president during the conflict. The different civil rights policies adopted in the First and Second World Wars reflect the differences berween a nascent and a full-blown civil rights movement, between President Wilson's commitment to segregation and President Roosevelt's aristocratic indifference to most racial issues, and between a Justice Department indifferent to civil liberties and a Justice Department staffed by committed racial liberals.

War often promotes gender equality as well as racial equality. The same mobilization concerns that provide increased opportunities for persons of color typically increase opportunities for women. The domestic needs for labor generared by a large-scale war offer new opportunities for women to gain positions from which they were previously excluded by law or by practice. When "men [are] away at war," Sara Evans notes, "women of all classes and races ha[ve] to assume a range of tasks traditionally allocated to men."29 Women are particularly likely to be beneficiaries of wartime labor shortages because they are perceived as Americans, at least as loyal as their fathers, husbands, and sons on the battlefield. When the absence of men creates labor shortages, women can be musted to take their place. Legal and nonlegal barriers to their participation fall by the wayside. During the Second World War, for example, women were given opportunities to volunteer for military service, businesses dropped formal and informal bans on women in certain jobs, and the War Labor Board fought to ensure that women who went to work were paid the same as men performing the same tasks. ${ }^{30}$

The ebb and flow of women's rights in the United States runs opposite to what the conventional story predicts. The traditional narrative highlights restrictive policies adopted during wartime, then regretted and abandoned when peace is restored. Lincoln's imposition of martial law was declared unconstitutional after Appomattox. ${ }^{31}$ The Japanese internment became a national embarrassment after the Second World War. ${ }^{32}$ The story of women's rights, however, is the opposite: liberties gained during wartime are abandoned when peace is restored. Women are encouraged to join the work force during wars when they are replacing absent men. They face renewed 
assertions of male supremacy after the troops come home and are accused of replacing present men.

\section{Jehovah's Witnesses (and Other Religious Minorities)}

The experience of Jehovah's Witnesses during the Second World War demonstrates that civil liberties as well as civil rights have been expanded during wartime. The Supreme Court of the United States in Minerswille School Dist. D. Gobitis (1940) by an $8-1$ vote ruled that a mandatory flag salure in public schools violated neither the free exercise nor free speech provisions of the First Amendment. ${ }^{33}$ That decision provoked two intense reactions. The first was a mass assault on Jehovah's Witnesses. Members of the sect who refused to salute the flag found their children expelled from schools, their property vandalized, and themselves victims of mob violence. ${ }^{34}$ The second was an élite assault on the Supreme Court. Prominent jurists and journalists excoriated the justices for failing to declare a constitutional right to refrain from saluting the flag. ${ }^{35} \mathrm{~A}$ judicial change of course soon ensued. Two years after Gobitis was decided, Justices Hugo Black, William O. Douglas, and Frank Murphy in an unprecedented opinion publicly confessed error. ${ }^{36}$ The next year, the Supreme Court by a 6-3 vote overruled Gobitis. ${ }^{37}$ Justice Robert Jackson's majority opinion in West Virginia State Board of Education D. Barnette famously asserted, "[i]f there is any fixed star in our constitutional constellation, it is that no official, high or petty, can prescribe what shall be orthodox in politics, nationalism, religion, or other matters of opinion or force citizens to confess by word or act their faith therein." 38

Gobitis may have been abandoned legislatively or by executive degree before being overruled judicially. Disturbed that the existing pledge of allegiance ceremony bore too close a resemblance to the Nazi salute, Congress in 1942 with the support of the American Legion passed a new law regulating public displays of loyalty. One provision in the bill stated that "citizens will always show full respect to the flag when the pledge is given merely by standing at attention." ${ }^{39}$ In an interpretation that was probably not intended by Congress, the executive branch immediately determined that the national legislature had preempted all state and local laws requiring students to salute the flag and recite the pledge of allegiance. "State and local regulations demanding a different standard of performance," Justice De- 
partment lawyers declared, "must give way entirely, or at least be made to conform." After 1942 officials in the Roosevelt administration specially decreed that "a school board order respecting flag salute exercises should not now be permitted to exact more of the pupil with religious scruples against the flag salute than that he should stand at attention while the exercise is being conducted." 40

Roosevelt's Justice Department more directly contributed to the overthrow of Gobitis by securing the appointments of two additional justices on record as thinking the case wrongly decided. Robert Jackson had expressed reservations abour Gobitis before his nomination. ${ }^{41}$ Wiley Rutledge, when a federal circuit court judge, condemned laws that required “Jehovah's Witnesses ... to choose between their consciences and public education for their children." 42 These executive actions meant that in 1943 the Supreme Court did not stand alone against a national majority committed to restricting religious freedom. Barnette was the consequence of a wartime effort sponsored by the executive branch of the national government to promote civil liberties.

Barnette belies two conventional claims about civil liberties during periods of military tension. First, constitutional decision makers during times of military tension are said to balance individual rights against national security. One value must, at least in part, be sacrificed to better secure the other value. Second, the balancing scale is thought to be biased toward national security. Military tensions, constitutional commentators generally agree, typically provide occasions for new, drastic limits on civil liberties and rights. Justice Oliver Wendell Holmes summed up accepted knowledge when in a unanimous opinion upholding a wartime restriction on political dissent, he declared, "When a nation is at war many things that might be said in time of peace are such a hindrance to its effort that their utterance will not be endured so long as men fight and that no Court could regard them as protected by any constitutional right." 43 When deciding the second flag salute case, however, Justice Jackson neither balanced free speech against national security nor ruled that national security justified new limits on political dissent. The judicial majority that struck down mandatory flag salutes insisted that protecting individual rights during a war promoted national security. Justice Jackson's opinion in Barnette referred specifically to "the fast failing efforts of our present totalitarian enemies" when commenting that " $[c]$ ompulsory unification of opinion achieves only the unanimity 
of the gravevard." Contrary to Justice Holmes, Americans were freer to refrain from saluting the flag during the Second World War than they were before Pearl Harbor.

Barnette was a wartime civil liberties decision, not merely a civil liberties case that happened to be handed down when the United States was at war. The flag salute ceremony became a national controversy only after Hitler took power in Germany and embroiled the world in total war. Disputes over whether persons in the United States had a right to refrain from saluting the flag arose as early as I 9 I 8 , but gamered little public attention. ${ }^{4}$ During the r 920 s and early 1930s, only members of tiny religious sects refrained from saluting the flag, few communities passed laws requiring children to salute the flag in school, and those communities that did pass such laws often did not strictly enforce them. Members of the Jehovah's Witnesses in the United States began refusing to salute the flag en masse only after being inspired by the example of Jehovah's Witnesses in the Third Reich who were persecuted for refusing to give the Nazi salute. ${ }^{45}$ American communities began rigidly enforcing laws mandating flag salutes only during the late 1930s, when the prospect of war in Europe heightened concerns with patriotism and inspired fears that members of Jehovah's Witnesses were fifth columnists. ${ }^{46}$ Justice Felix Frankfurter's opinion in Gobitis was clearly influenced by the fall of France only a few months earlier. ${ }^{47}$

The Second World War played a prominent role in the arguments for and against the consritutionality of the mandatory flag salute. Proponents regarded the Jehovah's Witnesses as "professed Nazi agents"48 and insisted that loyalty ceremonies were particularly vital during wartime. " $[\mathrm{T}]$ his is not the time for Jehovah's Witnesses . . . to be engaged in a nationwide program teaching disloyalty to our flag," the national commander of the American Legion declared, "when our supreme effort is needed for the unification of all elements toward our national safety."49 Prominent citizens, who during the r940s defended the right to refrain from saluting the flag, consistently analogized mob violence against Jehovah's Witnesses to "nazi methods" $"$ and compulsory flag salutes in the United States to compulsory saluting in Germany. The New Republic in an editorial condemning Gobitis asserted that the United States was "in great danger of adopting Hitler's philosophy in the effort to oppose Hitler's legions." "Such procedure ... would be understandable in Germany," the Christian Century complained when welfare was denied to Jehovah's Witnesses who refused to take part in 
flag ceremonies. "There a man either gives the nazi salute and votes $J a$ when ordered or else he starves." 52

The Second World War did much to promote religious freedom in general by linking religious bigorry with the Nazi state. Fighting an enemy identified with religious persecution, American leaders highlighted the more religiously inclusive elements of the country's political and constitutional heritage. "The gruesome persecution of religious minorities in Germany," Shawn Francis Peters asserts, "horrified many Americans and prompted them to tout the religious liberties enjoyed by members of all faiths in this country." 53 Many cases that served as vital precedents for expanding religious and other liberties during the Warren Court era were decided during the Second World War, partly as a judicial response to Nazism. ${ }^{54}$ Jews, in particular, were domestic beneficiaries of increased calls for religious tolerance. ${ }^{55}$ "With the Japanese attack on Pearl Harbor" and America's entry into the Second World War, Benjamin Ginsburg declares, "anti-Semitic activity was temporarily discredited through its association with the national enemy."56 Immigration curbs remained, but greater governmental efforts were made to prevent assaults on Jews by various hate groups. Businesses and universities began abandoning religious discrimination during the waning years of the Second World War. ${ }^{57}$

\section{The Eight-Hour Day during the First World War}

The First World War was a boon to workers who supported the war effort. Mobilization needs, combined with an executive predisposed to support moderate labor demands, led to increased federal power to mandate the conditions of labor and new statutory rights for workers. Pre-war constitutional doctrine had cast doubt on whether government could give statutory rights to workers that they could not gain at the bargaining table. ${ }^{58}$ Congress was disinclined to pass such measures. The threat of war changed the direction of public policy. When railway workers in 1916 threatened a strike to achieve an eight-hour day, the Wilson administration proposed and Congress passed the Adamson Act, mandating the eight-hour day. ${ }^{59}$ The Supreme Court sustained that law in Wilson v. New. ${ }^{60}$

The impending war in Europe played a crucial role in these decisions to expand the rights of workers. President Wilson's address to Congress in 
I916 demanded passage of the Adamson Act because "we cannot in any circumstances suffer the nation to be hampered in the essential matter of national defense." 61 When management in the winter of 1917 refused to adhere to the law, seeking a test case in the Supreme Court, Wilson placed great pressure on industrial leaders to grant the eight-hour day for reasons of national security. Shortly after the Germans torpedoed three American ships, he informed the National Conference Committee of the Railroads that "in this time of national peril ..., a general interruption of the railway traffic of the country . . . would entail a danger to this nation." 62 Presidential threats to do whatever was necessary to avoid a strike succeeded. Management agreed not only to accept the eight-hour day, but to maintain the eight-hour day even if the Supreme Court ruled the Adamson Act unconstitutional. ${ }^{63}$

The Supreme Court's decision the next day to uphold the constitutionality of the Adamson Act was similarly influenced by a war which would be declared a mere three weeks after the ruling was handed down. ${ }^{64}$ Chief Justice Edward White's opinion spoke of emergencies in general as providing justification for powers. ${ }^{65}$ All recognized that the threatened emergency was not simply the train strike, but a train strike when the United States was about to engage in military action. ${ }^{66}$ Attorney General Thomas Gregory observed that the Chief Justice "knew, as we all knew, that we were on the very verge of War; for the moment he forgot the facts of the case that was before him and his prophetic eye was resting on the immediate future when every proper energy of our country would be called upon to sustain it in its hour of greatest need." 67 Justice Pierce Butler was more explicit when in Highland D. Russell Car of Snow Plow Co., No. 8 he declared that "the war power of the nation" was an instance where "Congress may regulate the making and performance of ... contracts whenever reasonably necessary to effect any of the great purposes for which the national government was created." $\$ 88$

Labor issues complicate assertions that war provides occasions for restricting civil rights and liberties. Conflicts between union and management are often over whose rights are to be protected and to what degree. Workers during the progressive era declared they had a right to limits on the workday. That right, while not recognized in American constitutional practice, is enshrined, along with the right to join a union, in the Universal Declaration of Human Rights. ${ }^{69}$ Employers during the Progressive era asserted that 
they had the right to determine the conditions under which they would contract for labor. This right was recognized in previous Supreme Court decisions protecting the freedom of contract. ${ }^{70}$ Thus, government labor policy during the First World War (and other wars) could not simply balance individual rights against national security. Contested notions of national security inevitably determined whose individual rights the government protected.

\section{Procedural Rights during the Cold War}

Many procedural reforms that took place during the due process revolution were self-consciously associated with the Second World War and the cold war. One consequence of military conflicts and struggles with totalitarian nations was that policymakers and justices increasingly regarded constitutional protections for criminal suspects as central to the democratic values that the United States was championing throughout the globe. Scholars note the influence of "aversive constitutionalism" " on American constitutional practice during the I940s and I950s. "Precisely because they provide a sharp idea of what the U.S. does not stand for," Kim Lane Scheppele documents, "Nazi Germany and the Soviet Union became irresistible points of reference ... on numerous occasions and in many doctrinal conceptions."72 "[T] he desire to articulate principles that distinguished America from the Soviet Union and Nazi Germany," Richard Primus writes, "contributed to a long line of liberal Supreme Court decisions from the Second World War through the Warren Era." "'3 Margaret Raymond agrees that "American constitutional criminal procedure and norms during the postwar period were defined in part in reaction to those negative totalitarian models." 74

Numerous majority, concurring, and dissenting opinions defending and extending the constitutional rights of persons accused of crimes pointed to the practices of nations with which the United States was engaged in hot and cold wars as models that Americans could not emulate. ${ }^{75}$ Justice Hugo Black's majority opinion in Ashcraft v. Tennessee, when declaring unconstitutional a coerced confession, favorably compared the United States to "certain foreign nations ... which convict individuals with testimony obtained by police organizations possessed of an unrestrained power to seize persons 
suspected of crimes against the state, hoid them in secret custody, and wring from them confessions by physical or mental torture."76 The majority opinion in Escobedo v. Illinois contrasted the right to counsel guaranteed by the Sixth Amendment to practices in the Soviet Union forbidding the presence of counsel when criminal suspects were interrogated. ${ }^{77}$ Permitting certain listening devices without adequate safeguards, Justice Douglas declared in Berger p. New York, "would take us closer to the ideological group we profess to despise.": Liberal commentators agreed with the Court. Erwin Griswold's lectures on the Fifth Amendment observed that the privilege against self-incrimination "would never be allowed by communists, and thus it may well be regarded as one of the signs which sets us off from communism."79

Aversive constitutionalism was primarily a wartime phenomenon. American élites promoted civil liberties by distinguishing the United States from totalitarian countries only when the United States was involved in a hot or cold war with those countries. Law reviews and judicial opinions during the I.930s did nor treat the gross violations of human rights in Stalinist Russia or Nazi Germany as reasons for Americans to provide greater protection for civil liberties at home. Germany became the model not to emulate only with the onset of the Second World War. ${ }^{80}$ The Soviet Union became the basis of comparison only with the onset of the cold war. ${ }^{81}$ When the cold war thawed, so did aversive constitutionalism. ${ }^{82}$ South Africa was rarely held up as a model to be avoided, even though that country's inhumane practices were well known. ${ }^{83}$

\section{Anti-imperialist Dissent during the Spanish-American War}

The McKinley administration's decision to declare war against Spain and send troops to quell rebellion in the Philippines brought forth the most vigorous dissent to the use of military force in American history. Professor Charles Eliot Norton of Harvard University "urged Harvard students not to enlist in a war in which 'we jettison all that was most precious of our national cargo. "\$4 American military intervention in the Philippines inspired even greater criticism of government policy. Such prominent politicians as William Jennings Bryan and Benjamin Harrison joined the Anti-Imperialist League, which issued frequent condemnations of administration policy. ${ }^{85}$ 
Charles Francis Adams Jr. praised the "very gallant resistance the unfortunate Filipinos are making against our wholly unprovoked assault upon them."86

These caustic attacks on military policy, which included explicit calls not to volunteer for military service, were not subject to any domestic censorship. The McKinley administration did make an abortive attempt to prevent Edward Atkinson from mailing anti-imperialist pamphlets to prominent figures in the Philippines, but Atkinson was allowed to mail more than 100,000 copies domestically. Encouraged by the sharp attacks on the administration's refusal to mail antiwar literature abroad, Atkinson issued another pamphlet intended as his "strongest bid yet for a limited residence in Fort Warren." 87 Chastened by the failure of its previous efforts, the McKinley administration did nothing. Attacks on military imperialism at the dawn of the twentieth century were allowed to be "uninhibited, robust, and wideopen," even though they "include[d] vehement, caustic, and sometimes unpleasantly sharp attacks on government and public officials." 88

Two factors explain why during the eighteenth and nineteenth centuries political dissent was suppressed during some military conflicts but not others. Persons not identified ideologically, ethnically, or racially with American enemies were free to protest against military involvements. Norton, Adams, and Atkinson were white conservatives protesting a war against an Asian opponent. White Whigs similarly protested against the Mexican War without having their loyalty challenged. When white critics of military policy had ethnic or ideological ties to national enemies, however, as during the American Revolution, the undeclared war with France, and the Civil War, dissent was suppressed. Until the Second Worid War, the War of I8I2 was the only instance of military combat in American history when white critics without official interference condemned a war against another nation identified as white. Existing attitudes about national power may have had an even greater influence on speech policies during wartime, correctly predicting national policy in every military engagement fought before the Second World War. For the first iso years of national existence, free speech was restricted only during wars in which the political party with the broader conception of national power controlled the presidency. Federalists (undeclared war with France) and Whig-Republicans (Civil War) limited political dissent when wars occurred on their watch. Jeffersonians (War of I 8 I2) and Jacksonians (Mexican War) did not. The stand-pat Republicans 
of the McKinley administration who did not repress speech during the Spanish-American War had a narrower conception of national power than the progressives in the Wilson administration who restricted speech during the First World War.

\section{Communists during the Second World War}

The good war was good for American communists. In the political environment of the early I940s, they were increasingly perceived as loyal Americans or identified with the main ally of the United States in the Second World War. The alliance between the United States and the Soviet Union inspired increased toleration for socialists, Marxists, and other members of the radical left. Americans, "appreciat[ing] the tremendous sacrifices in blood the Soviet Lnion was making to defeat Nazi Germany," developed a more "benign riew" of the country. ${ }^{89}$ American liberals, appreciating the support that domestic communists gave to the New Deal, frequently supported communists seeking leadership positions in labor unions and running for local, state, and federal offices. ${ }^{90}$

Communist support for the domestic and foreign policy of the Roosevelt administration, combined with concomitant perceptions of communists' loyalty, helped reduce significantly the number of Americans who favored legislation curtailing subversive activities. Opinion polls by 1945 found that popular majorities no longer supported new bans on radical left-wing speech. $^{91}$ Government officials, responding to both communist support and shifts in public artitudes, sharply reduced the repression of radical activists. William Wiecek declares, "the wartime Grand Alliance temporarily abated antisubversive activiry aimed at leftists." The Second World War, he continues, "marked the nadir of anticommunism" in the United States. ${ }^{92}$ Federal prosecutors remained on the sidelines as communist influence in American life increased substantially. Mobilization as well as loyalty concerns fostered a more tolerant public policy. The Roosevelt administration did not aggressively pursue efforts to deport radical labor leaders for fear of inducing strikes and work stoppages. ${ }^{93}$ This reduced government surveillance hardly made the early I940s halcyon days for the radical left. Still, Americans during the Second World War were far freer to join groups 
associated with the Communist Party and express support for communist goals than either before or after.

The Supreme Court during and immediately after the Second World War upheld the civil liberties claim in all three cases brought by communists or persons affiliated with communists. Justice Black in Lopett p. United States ruled that legislation cutting off the salaries of named federal employees declared by Congress to be subversives was an unconstitutional bill of attainder. His opinion noted administration opposition to the bill and quoted representatives who declared the law a "legislative lynching."94 The justices in Bridges $p$. Wixon ruled that labor leaders who cooperated extensively with communists were not affliated with communists for purposes of federal deportation law. Justice Douglas highlighted the Grand Alliance as establishing that good Americans could legitimately cooperate with organizations associated with the Soviet Union. "Certainly those who joined forces with Russia to defeat the Nazis," he wrote, "may not be said to have made an alliance to spread the cause of Communism." ${ }^{\text {"95 }}$ Most significantly, the judicial majority in Schneiderman v. United States made clear that long-standing members of the Communist Party could be "attached to the principles of the constitution of the United States" as that phrase was used in citizenship law. Justice Murphy declared, "we certainly will not presume in construing the naturalization and denaturalization acts that Congress meant to circumscribe liberty of political thought by general phrases." The procedures for amending the Constitution set forth in Article $\mathrm{V}$ "and the many important and far-reaching changes made in the Constitution since 1787 ;" he continued, "refute the idea ... that one who advocates radical changes is necessarily not attached to the Constitution." "96

The Supreme Court proved just as receptive during the Second World War to the civil liberties of persons who sympathized with the Nazi cause, at least those who did so in word but not in deed. ${ }^{97}$ The federal government moved far more aggressively against domestic Nazis than domestic communists during the first half of the I940s, but six of the seven convictions that reached the Supreme Court were reversed..$^{98}$ Each reversal was on statutory grounds. Nevertheless, the justices made clear that they would be far less willing to find Nazi activities illegal under federal law than courts had been in analogous cases during and immediately after the First World War. " $[M]$ en are not subject to criminal punishment because their conduct of- 
fends our patriotic emotions or thwarts a general purpose sought to be effected by specific commands which they have not disobeyed," the majority opinion in Viereck v. United States declared. ${ }^{99}$ The justices in Keegan p. United States ruled that persons could not be convicted of obstructing the draft for counseling others that the draft was unconstitutional, a claim nearly identical to assertions that had sent Charles Schenck to jail in 1918. ${ }^{100}$ Justice Murphy in Hartzel v. United States, while not questioning whether the Espionage Act of 1917 was constitutional, cited Justice Holmes's dissent,in Abrams $\mathfrak{D}$. Cnited States ${ }^{101}$ as authority for interpreting the statute as requiring proof of a specific intent to interfere with military recruitment. Pamphlets that "depict [ed] the war as a gross betrayal of America, denounce [d] our English Allies and the Jews and assail [ed] in reckless terms the integrity and patriotism of the President of the United States," under this standard, were "not enough by [themselves] to warrant a finding of criminal intent." 102 Justice Jackson, after ruling in Cramer p. United States that the government had failed to produce two witnesses to an overt act of treason, concluded with Thomas Paine's admonition: "[h]e that would make his own liberty secure must guard even his enemy from oppression."'103

Existing attitudes toward free speech and civil liberties explain why persons identified ideologically and ethnically with Germans were less likely to be prosecuted and convicted, and to have their convictions sustained on review, during the Second World War than during the First. Paul Murphy points out that progressives during the first fifteen years of the twentieth century were not sympathetic to civil liberties claims of any sort, whether claims of property rights or of free speech rights. Most progressives were committed utilitarians who believed that individual rights were subordinated to the public good. When war broke out, progressives in all branches of the national government were predisposed to restrict both rights to free speech and rights to public property in the name of national security. ${ }^{104}$

Civil liberties enjoyed far more support in the Roosevelt administration. Franklin Roosevelt may not have belonged to the American Civil Liberties Union, but many of his trusted advisors did. Attorney General Francis Biddle was a particularly strong supporter of civil liberties. He entered office believing that " $[t]$ he extravagant abuse of prosecutions for sedition had been the most serious example of hysteria in the First World War." When local federal attorneys arrested opponents of the war for utterances 
that Biddle thought "palpably innocuous," he "ordered that the men be released and the prosecutions dropped." ${ }^{105}$ Federal justices were similarly far more predisposed to protect civil liberties during the Second World War than during the First World War. The Supreme Court during the first two decades of the twentieth century rejected every free speech claim presented to the justices. ${ }^{106}$ The justices during the I930s provided increased support for civil liberties ${ }^{107}$ and, in an important footnote, indicated that protecting free speech was a central judicial function. ${ }^{108}$

\section{Overall}

These counter-stories, while not presenting a comprehensive account of freedom when the United States is at war, seem at least as representative of individual rights policies during wartime as the well-known instances when the government restricted rights. For every instance in which government restricted civil liberties during wartime, another instance exists when government policy remained the same, and still another when an individual right was expanded. For every Japanese-American sent to an internment camp, there is an African American freed from Jim Crow. For every A. Mitchell Palmer, there is a Francis Biddle. Developing more precise measures of civil rights and liberties during wartime may be impossible. Any effort to determine statistically whether the restrictions on Japanese-Americans during the Second World War were greater than the improvements in the status of African Americans will depend too heavily on the researcher's values implicit in the measurements. Like the proverbial apples and oranges, some policies are simply not capable of precise comparison.

The best that scholars are likely to do is identify certain patterns in wartime behavior. If the analysis above is correct, these patterns have less to do with war per se than with the presence of specific conditions during a war. Both the conventional stories and counter-stories suggest that civil rights policies when the United States is at war are determined by mobilization needs, the ideological justification for the war, the identity of potential rights holders, and the predispositions of crucial political actors. These conditions help explain policy in previous wars and in the contemporary war against terrorism, which has created opportunities for expanding rights unrecognized by too many commentators. 


\section{War and Politics}

Many stories are already being told about civil rights and civil liberties during the present war against terrorism. As always, the narratives tend to be of civil rights and civil liberties restricted in wartime. Critics complain about decisions by the Bush administration to engage in ethnic profiling, hold numerous persons in detention without trial, deprive detainees of the assistance of counsel, use military courts, and remove previous restrictions on the means that law enforcement officials may use when investigating both terrorists and ordinary criminals. As has historically been the case, the victims of these policies are typically identified ideologically or, more important, ethnically with the enemy. Liberal white critics speak freely against the war, while many ethnic Arabs previously uninterested in politics have been detained and humiliated by government officials. ${ }^{109}$

Important counter-stories can also be told about civil liberties and civil rights protected and expanded during the war against terrorism. Military experts long indifferent to privacy rights are now insisting that bans on gays in the militar be abandoned during the present crisis. The Bush administration is steadfastly refusing to adopt anti-terrorist policies that might infringe the claimed Second Amendment rights of gun owners. (The administration's successful defense of gun rights during the war against terrorism is a counter-story, no matter what the proper interpretation of the Second Amendment. Gun control at present is a counter-story because the Bush administration believes that citizens have a constitutional right to bear arms and is successfully preserving this claimed liberty during a time of military conflict.) The Supreme Court's decision in Grutter v. Michigan, sustaining an affirmative action program, was heavily influenced by a brief submitted by retired military officers which asserted that race-conscious measures were necessary for national security. ${ }^{110}$ These counter-stories highlight ongoing themes about civil. liberties during wartime and raise questions about the extent to which contemporary policy is driven by objective national security needs or the low value that the Bush administration places. on particular civil rights and liberties.

Several contemporary policies illustrate how previous commitments shape official responses to a military conflict. When governing officials had previously championed a particular civil liberty (as members of the Bush administration did with gun rights), they are likely to regard the military 
conflict as either supporting their position or having no bearing on it. Thus, in addition to defending the rights of gun owners during the war against terrorism, President Bush has maintained that the military siruation makes imperative the enactment of tax cuts that his administration was touting before the attack on the World Trade Center. Liberals exhibit a similarly steadfast commitment to pre-war policies. Senator Edward Kennedy and others seek to restrict only those rights that they sought to restrict before terrorist concerns occupied policymakers. The major critics of Bush administration gun and tax policies after September I I were also the major critics of administration gun and tax policies before September I I.

These recent counter-stories indicate the ways in which war may exercise a powerful indirect effect on civil rights and civil liberties by changing the power relationships between political actors. Military tensions affect institutional support in fairly predictable ways. Presidents experience strong short-term surges in popularity. ${ }^{111}$ Power flows to the national government at the expense of the states. ${ }^{112}$ Trust in the military increases substantially. ${ }^{113}$ These shifts in public opinion privilege policies favored by the president as opposed to Congress, by national officials as opposed to state officials, and by the military as opposed to civilians. The fate of particular civil liberties and rights in wartime thus may depend on whether the military crisis effectively transfers power to political actors inclined to support that liberty or right. Affirmative action was a beneficiary of the war against terrorism because that war increased the power of a military previously committed to obtaining a racially diverse armed forces.

Civil liberties and civil rights policies during previous wars are also at least partly explained as indirect consequences of changes in public support for various political institutions and actors. The First World War was good for labor because a president favoring an eight-hour day had strong public support in 1917. The Second World War facilitated racial liberalism by transferring power from conservative states and a Congress dominated by a conservative bloc to presidents that had fairly liberal Justice Departments. The war against terrorism has served as a vehicle for restricting civil liberties largely because the events of September I I increased public support for an administration predisposed to regard foreign nationals as having few rights and more than willing to find any excuse to abandon existing legal limits on criminal investigations.

The counter-stories about civil rights and civil liberties that can be told 
about past and present wars require a reworking of the conventional case against the Bush administration's policies. Most civil libertarians contend that while civil rights and liberties are always restricted in war, the Bush administration is going too far. War, in their view, inevitably requires citizens to sacrifice some liberties, just not as many as John Ashcroft and his political associates demand. Alan Brinkley's sharp attack on contemporary policy nevertheless acknowledges that "in times of national emergency, .... the relative claims of order and security naturally become stronger."114 Critics are right that civil rights and civil liberties have often been limited during war in the name of national security. Restrictive policies, however, are hardly inevitable when war breaks out. No particular civil right or liberty has been restricted whenever the United States has been involved in a hot or cold war. War has often generated arguments for protecting and increasing civil rights and liberties. History makes clear that when faced with similar circumstances in past wars, other administrations have made policy choices different from those of the Bush administration. Every contemporary policy to restrict some rights while protecting others is a subjective choice, not mandated by historically recognized national security needs.

A different administration would have made a different, more civil libertarian response to the events of September II. Concerned with American reputation abroad, a Justice Department staffed by civil libertarians would have emphasized the need to treat foreign nationals with increased respect during the war against terrorism. As during the Second World War and the cold war, American élites during a war that has been advertised as necessary to protect American freedoms would have highlighted such paladins of liberty as the right to counsel and trial by jury. Gun ownership would have been the paradigmatic liberty that had to be restricted in time of war. Increased taxes would be defended as simply a pale imitation of the sacrifices that American soldiers are making abroad.

Americans need to be more fully aware of the counter-stories about civil rights and liberties. War, history demonstrates, simultaneously creates opportunities to increase and restrict the freedom in the United States. Which opportunities are taken advantage of depends largely on who has the power to tell the official stories. One moral of the above story is that the major threat to civil rights and liberties at present is less what happens to civil liberties in wartime than what happens to civil liberties when George Bush 
is presiding during wartime. Another moral is that if the war against terrorism involves a struggle for the hearts and minds of persons in the third world, crucial battles are more likely to be won by a renewed emphasis on American commitments to diversity and respect for the strangers among us than by championing conceptions of individual rights largely limited to gun ownership and low tax rates.

\section{Notes}

I John C. Miller, Crisis in Freedom: The Alien and Sedition Acts ( $195 \mathrm{r}$ ).

2 Mark E. Neely Jr., The Fate of Liberty: Abraham Lincoln and Civil Liberties (1991).

3 William Preston, Aliens and Dissenters (1963); Paul L. Murphy, World War I and the Origin of Civil Liberties in the United States (1979); Schenck v. United States, 249 U.S. 47 (r919).

4 Jacobus tenBroek, Edward N. Barnhart, and Floyd W. Matson, Prejudice, War and the Constitution (1968); Duncan v. Kahanamoku, 327 U.S. 304 (1946); Korematsu v. United States, 323 U.S. 214 ( 1944 ); Hirabayashi v. United States, 320 U.S. 8I ( 1943 ).

5 Stanley I. Kutler, The American Inquisition: Justice and Injustice in the Cold War (1984); Dennis v. United States, 34I U.S. 494 ( I95 I).

6 Richard C. Leone and Greg Anrig Jr., eds., The War on Our Freedoms: Civil Liberties in an Age of Terrorism (2003).

7 See Mark Tushnet's chapter "Defending Korematsu?"

8 Samuel Eliot Morison, Frederick Merk, and Frank Freidel, eds., Dissent in Three American Wars (1970).

9 See Mary L. Dudziak, Cold War Civil Rights: Race and the Image of American Democracy (2000); Philip A. Klinkner and Rogers M. Smith, The Unsteady March: The Rise and Decline of Racial Equality in the United States (1999).

IO 319 U.S. 624.

II 310 U.S. 586.

I2 In keeping with the story-telling nature of the analysis, I offer no rigid definition of war or a period of military tension. The exclusion or inclusion of a few borderline cases would not change the analysis.

I3 The conditions below are largely derived from the pioneering work of Philip Klinkner and Rogers Smith on war and racial equality. Klinkner and Smith, The Unsteady March. Their study suggested that three conditions were necessary for Americans to make substantial progress toward racial equality. My more general analysis of civil rights and civil liberties adopts their first condition in toto, 
slightly modifies their second condition, significantly expands their third condition, and adds a new condition.

14 Klinkner and Smith, The Unsteady March, 3.

I5 Id. at 3 .

I6 Klinkner and Smith emphasize "domestic political protest movements willing and able to bring pressure upon national leaders." Id. For reasons discussed below, the predispositions of national leaders have historically had as great an influence on civil rights and civil liberties policy in wartime.

I7 Neither the conventional stories nor the counter-stories tell of the Vietnam War. That conflice generated significant efforts to limit, maintain, and expand civil liberties. The reason for the intense conflict, which I hope to explore in a larer essay, is that conditions were present for both increasing civil liberties (Congress predisposed to protect rights, white Americans protesting a war against a nation of color) and restricting civil liberties (execurive branch predisposed to limir rights, protestors identified with communist enemies). Berta Esperanza Hernandez-Truyol, "Women's Rights as Human Rights: Rules, Realities and the Role of Culture: A Formula for Reform," 2I Brooklyn Journal of International Law 605, 652 (1996).

I9 Sara M. Evans, Born for Liberty: A History of Women in America (1989), 227-29, 244-50.

Derrick A Bell Jr., "Brown v. Board of Education and the Interest-Convergence Dilemma," 93 Harvard Law Rewiew 518, 524 (1980).

Dudziak, Cold War Civil Rights (2000), I2.

Id. at IOo-IoI.

23 Klinkner and Smith, The Unsteady March, 12-23.

$24 \mathrm{Id}$. at 63 , see also $52-7 \mathrm{I}$.

$25 \mathrm{Id}$. at $\mathrm{I} 6 \mathrm{I}-287$.

26 See Leonard Wibberley, The Mouse That Roared (1985).

27 Klinkner and Smith, The Unsteady March, 3.

28 Id. at 4.

29 Evans, Born for Liberty, 53.

$30 \mathrm{Id}$. at 222.

31 See Ex parte Milligan, 7 U U.S. 2 (I866).

32 Tushnet, “Defending Korematsu?," this collection.

333 ro U.S. 586 (1940).

34 Shawn Francis Peters, Judging Jehovah's Witnesses: Religious Persecution and the Dawn of the Rights Revolution (2000), I-I I, 72-95, I IO-13, I24-27, 134-78, 2II-I6, 267-73, 28I-84; Victor W. Rotnem and F. G. Folsom Jr., "Recent Restrictions upon Religious Liberty," 36 American Political Science Review 1053, $1061-63(1942)$. 
35 Peters, Judging Jehovah's Witnesses, 67-69.

36 Jones v. Opelika, 3 I6 U.S. 584, 623-24 (I942) (Black, Douglas, and Murphy, J., dissenting).

37 West Virginia State Board of Education v. Bamette, 3 I9 U.S. 624, 642-43 (1943).

38 Barnette, 3 I9 U.S. at 642. One month before handing down Bamette, the Supreme Court in Murdock v. Pennsylvania, 319 U.S. 105 (1943), held that Jehovah's Witnesses selling religious books could not constitutionally be required to pay a generally applicable licensing fee on peddlers. This decision overruled Jones v. Opelika.

39 Peters, Judging Jehovah's Witnesses, 246.

40 Rotnem and Folsom, "Recent Restrictions upon Religious Liberty," 1064. See Peters, Judging Jehovah's Witnesses, 245-46, 252; Barnette, 3 I 9 U.S. at 638.

4 I Peters, Judging Jehovah's Witnesses, 238-39.

42 Busey v. District of Columbia, I29 F.2d 24, 38 (D.C. Cir. I942) (Rutledge, )., dissenting). See Francis Biddle, In Brief Authority (1962), I93.

43 Schenck v. United States, 249 U.S. 47, 52 ( I919).

44 David R. Mainwaring, Render unto Caesar: The Flag-Salute Controwersy ( 1962), I I.

45 Peters, Judging Jehovah's Witnesses, 24-25.

46 Id. at $9,12-13,16,73-76,80,84,92,100,106-8$, II 2 .

47 Id. at 52-60, 65 .

48 Peters, Judging Jehovah's Witnesses, 73.

49 Id. at I I0, see also I 56-57, I6I, 194-95.

5o Id. at 97 (quoting Francis Biddle), see also 75, 86, 96-98.

5 I Id. at 69. See Rotnem and Folsom, "Recent Restrictions upon Religious Liberty" I063 " would be if the flag salute itself were made a practical daily exercise of a fundamental liberty, a liberty which is one of the four great freedoms for which this nation is now fighting!').

52 Peters, Judging Jehowah's Witnesses, 163.

53 Id. at 16.

54 Id. at $14-16,290-94$.

55 Increased tolerance at home did not, however, translate inro any greater willingness to prevent horrible. Jewish suffering abroad. See David $S$. Wyman, The Abandonment of the Jews: America and the Holocaust, 194I-1945 (1984).

56 Benjamin Ginsburg, The Fatal Embrace: Jews and the State (1993), I 19.

57 Id. at 99.

58 See, for example, Lochner v. New York, I98 U.S. 45 (r905).

59 See Arthur S. Link, Woodrow Wilson and the Progressive Era, I9I0-I9I7 (1954), $235-37$. 
60243 U.S. 332 (I9I7).

6I 38 The Pubiic Papers of Woodrow Wilson (Arthur Link ed. 1982) IOI.

62 4I The Public Papers of Woodrow Wilson (Arthur Link ed. 1982) 4 I 4.

63 Id. at 43 I n. 2; see Link, Woodrow Wilson and the Progressive Era, 237 n. 34.

64 See Michal R Belknap, "The New Deal and the Emergency Powers Doctrine," 62 Unipersity of Texas Law Review 67, 79 (1983).

65 Link, Woodrow Wilson and the Progressive Era, 347-52.

66 See also Oren Gross, "Chaos and Rules: Should Responses to Violent Crises Always Be Constitutional?" I 22 Yale Law Journal Ior I, 1063-64 (2003).

67 Belknap, "The New Deal and the Emergency Powers Doctrine," 80 n. 93.

68279 U.S. 253, 26I-62 (1929). See Belknap, "The New Deal and the Emergency Powers Doctrine," 82-84.

69 Article 24 declares, "Everyone has the right to rest and leisure, including reasonable limitation of working hours and periodic holidays with pay." Article 23, Section +, declares, "Everyone has the right to form and to join trade unions for the protection of his interests." Universal Declaration of Human Rights, www.un.org/rights/50/decla.htm.

70 See note 58 , above.

7I Kim Lane Scheppele, "Aspirational and Aversive Constitutionalism: The Case for Studying Cross-constitutional Influence through Negative Models," I ICON 296, 3 I2 (2003). This paragraph is heavily indebted to Scheppele's important article.

72 Id. at 313 .

73 Richard Primus, "A Brooding Omnipresence: Totalitarianism in Postwar Constitutional Thought," I06 Yale Law Joumal 423, 423 ( 1996).

74 Margaret Raymond, "Rejecting Totalitarianism: Translating the Guarantees of Constitutional Criminal Procedure," 76 North Carolina Law Review 1 193, I I97 ( 1998$)$.

75 For the examples discussed below and others, see Raymond, "Rejecting Totalitarianism?" 1 203-20.

76 Ashcraft v. Tennessee, 322 U.S. 143 , I 53 (1944).

77378 U.S. 478,488 n. 9 ( 1964 ) (" $[t]$ he Soviet criminal code does not permit a lawyer to be present during the investigation").

78388 U.S. 4 r, 67-68 (Douglas, J., concurring).

79 Erwin N. Griswold, The Fifth Amendment Today (Cambridge: Harvard University Press, 1955), 8I.

80 Primus, "A Brooding Omnipresence," 429, 437.

81 Raymond, "Rejecting Totalitarianism," I 2 ro.

82 See Raymond, "Rejecting Totalitarianism," I 220.

83 For the rare exception, see Florida v. Bostick, 50I U.S. 429, 443 (I99I) (Marshall, $J$., dissenting). 
84 Frank Freidel, "Dissent in the Spanish-American War and the Philippine Insurrection," Morison, Merk, and Freidel, eds., Dissent in Three American War, 74.

85 See Robert L. Beisner, Tipelpe against Empire: The Anti-Imperialists, 1898-1900 (I985).

86 Friedel, "Dissent in the Spanish-American War," 83.

87 Id. at 85 .

88 New York Times Co. v. Sullivan, 376 U.S. 254, 270 (r964).

89 Harvey Klehr and John Earl Haynes, The American Communist Mopement: Storming Heaven Itself (1992), 102.

90 Id. at 100-Ior.

9 I Id. at ror.

92 William M. Wiecek, "The Legal Foundations of Domestic Anti-Communism: The Background of Dennis p. United States," 2001 Supreme Court Review 375, 403.

93 Biddle, In Brief Authority, 300-302.

94 Lovett v. United States, 328 U.S. 303, 309 ( I946).

95 Bridges v. Wixon, 326 U.S. I35, I43 (1945).

96320 U.S. II8, I32, I37 (1943).

97 The justices had no difficulty permitting Nazi saboteurs to be tried by a military court, even though civilian courts were open in the jurisdictions where their offenses were alleged to have taken place. Ex parte Quirin, $3 I_{7}$ U.S. I ( 1942 ).

98 In addition to the cases discussed below, see Fiswick v. United States, 329 U.S. 211 ( 1946 ) (claim that petition in 1940 concealed membership in the Nazi party cannot be proved by evidence that petitioner supported the Nazis after 1940); Baumgartner v. United States, 322 U.S. 665 (1944) (evidence that a naturalized citizen supported the Nazis during the late 193 os cannot be used to prove that he falsely declared loyalty to the"United States when becoming a citizen in 1932). The one case in which the Court ruled against a Nazi sympathizer was Knauer v. United States, 328 U.S. 654 (I946) (evidence at the time of naturalization supported finding that petitioner falsely swore allegiance to the United States).

993 I8 U.S. 236, 245 (1943).

I00 Keegan v. United States, 325 U.S. 478 (1945). See Schenck v. United States, 249 U.S. 47 ( 1919 ).

10I 250 U.S. 616,627 (I919).

102322 U.S. $680,683,689$ (1944).

I03 Cramer v. United States, 325 U.S. I, 48 (1945).

I04 Paul L. Murphy, World War I and the Origin of Civil Liberties in the United States ( 1979). See Mark A. Graber, Transforming Free Speech: The Ambiguous Legacy of Civil Libertarianism (1991), 78-86.

Ios Biddle, In Brief Authority, 233-34. Significantly, perhaps, the decision to intern Japanese-Americans was made by War Department officials not noted for their 
previous commitment to racial and ethnic equality. The Justice Department under Biddle privately opposed the policy. See $i d$. at 219, 226.

ro6 See Fox v. Washington, 236 U.S. 273 (1915); Patterson v. Colorado, 205 U.S. 454 ( 1907$)$.

107. See Herndon v. Lowry, 301 U.S. 242 (1937); Near v. Minnesota, 283 U.S. 687 (r93I); Stromberg v. California, 283 U.S. 359 (193I).

ro8 United States v. Carolene Products Co., 30I U.S. I44, I52-53 n. 4 (1938).

rog See Alan Brinkley, "A Familiar Story: Lessons from Past Assaults on Freedoms," Leone and Anrig, eds., The War on Our Freedoms, 46; Lelyveld, "The Least Worst Place," Leone and Anrig, eds., The War on Our Freedoms, 124.

IIO 539 U.S. 306 (2003).

III See John E. Mueller, "Presidential Popularity from Truman to Johnson," 64 American Political Science Review 18, 20-22 (1970).

I12 Richard C. Leone, "The Quiet Republic," Leone and Anrig, eds., The War on Our Freedoms, 16.

I 3 See David C. King and Zachary Karabell, The Generation of Trust: Public Confidence in the U.S. Military since Vietnam (Washington: AEI Press, 2003).

II4 Brinkley, "A Familiar Story," 23. See Stephen J. Schulhofer, "No Checks, No Balances: Discarding Bedrock Constitutional Principles," Leone and Anrig, The War on Our Freedoms, 74; Leone, "The Quiet Republic," I2. 